\title{
The Effect Of Internal Audit On The Implementation Of Good Corporate Governance (GCG) In PT. Bank XYZ In Surabaya
}

\author{
Bima Satya Wiratama dan Iga Aju Nitya Dharmani \\ Program Studi Manajemen, Fakultas Ekonomi Dan Bisnis \\ Universitas Narotama Surabaya \\ Email author: aju.dharmani@narotama.ac.id
}

\begin{abstract}
To improve the Bank's performance, protect the stakeholder's needs, and improving compliance with the applicable laws and generally accepted ethical values in the banking industry, the Bank should conduct its operations in GCG. One of them is the assessment of the GCG's implementation between the Internal Audit function. The research aims to determine the Internal Audit's role in the implementation of GCG. The variable of this research is the Internal Audit (X) as an independent variable, and then implementation of GCG $(Y)$ as the dependent variable. The research is using a simple linear regression analysis techniques to test the hypothesis. The data used in this research is primary data, where it was obtained through questionnaires. The population is 25 respondents, which means that all respondents were sampled. Respondents came from the Internal Audit Unit of PT. Bank XYZ. The Results are showing the coefficient of Internal Audit (X) on the application of GCG is 11,088 with a significance level is $0,00<$ 0,05 . So the null hypothesis (Ho) is rejected and then the alternative hypothesis $(\mathrm{Ha})$ is accepted. In other words, it has a significant influence. Results of the test determination using the formula coefficient of determination, Internal Audit influenced $84 \%$ of GCG implementation. The rest was influenced by other factors that aren't included in this research.
\end{abstract}

\section{Keyword}

Internal audit, Good Corporate Governance, Bank

\section{Pendahuluan}

\subsection{Latar Belakang}

Krisis ekonomi tahun 1997-1998 yang menerpa Indonesia dan beberapa negara lain dikawasan Asia menimbulkan sebuah keruntuhan ekonomi secara besar-besaran. Banyak akibat buruk yang timbul akibat krisis ekonomi tersebut, salah satunya perusahaan-perusahaan baik swasta nasional maupun asing berjatuhan karena tidak mampu bertahan.

Kasus yang terjadi pada beberapa perusahaan yang terpaksa gulung tikar, membuktikan bahwa terdapat pengawasan dan pengendalian kinerja perusahaan yang buruk. Hasilnya perusahaan gagal dalam menjalankan rencana strategis.

Kesadaran untuk menerapkan GCG termasuk di dalam dunia perbankan pun semakin meningkat. Penerapan tata kelola yang baik diharapkan dapat membawa dampak positif yang dapat mengangkat citra bank tersebut dikalangan investor, pemerintah, maupun masyarakat.

Berdasarkan Surat Edaran Bank Indonesia (SEBI) No. 15/15/DPNP tanggal 29 April 2013 perihal Pelaksanaan GCG bagi Bank Umum, dalam rangka meningkatkan kinerja bank, melindungi kepentingan stakeholders, dan meningkatkan kepatuhan terhadap peraturan perundang-undangan yang berlaku serta nilai etika yang berlaku umum pada industri perbankan, bank wajib melaksanakan kegiatan usahanya dengan berpedoman prinsip GCG. Pelaksanaan GCG pada industri perbankan harus senantiasa berlandaskan pada 5 (lima) prinsip dasar yaitu transparansi (transparency), akuntabilitas (accountability), pertanggungjawaban (responsibility), independensi (independency), kewajaran (fairness). Sistem corporate governance yang baik memberikan perlindungan efektif kepada para pemegang saham dan pihak kreditur, sehingga mereka bisa meyakinkan dirinya akan memperoleh kembali investasinya dengan wajar dan bernilai tinggi.

Salah satu pihak yang terkait dengan pelaksanaan prinsip GCG adalah Audit Internal. Audit Internal dibentuk guna membantu manajemen agar mereka dapat menjalankan tanggung jawab secara efektif dan efisien. Dengan 
dibentuknya Audit Internal, diharapkan manajemen dapat mencurahkan perhatiannya pada tugas pengelolaan, sedangkan tugas pengendalian sehari-hari atas kegiatan usaha sebuah perusahaan dapat dilaksanakan secara lebih intensif dan efektif tanpa mengurangi tanggung jawabnya (Standar Pelaksanaan Audit Internal Bank, 2011). Menurut Hery (2010:93), definisi audit internal adalah:

"Auditor internal memiliki fungsi untuk memeriksa dan menilai baik buruknya pengendalian atas akuntansi keuangan dan operasi lainnya, Memeriksa sampai sejauh mana hubungan para pelaksana terhadap kebiijakan, rencana dan prosedur yang telah ditetapkan, Memeriksa sampai sejauh mana aktiva perusahaan dipertanggungjawabkan dan dijaga dari berbagai macam bentuk kerugian, memeriksa kecermatan pembukuan dan data lainnya yang dihasilkan oleh perusahaan, Menilai prestasi kerja para pejabat/pelaksana dalam menyelesaikan tanggung jawab yang telah ditugaskan."

Berdasarkan pengertian diatas tampak bahwa pelaksanaan Audit Internal sangat berperan bagi manajemen yang telah menerapkan pengendalian internal yang merupakan bagian dari suatu perusahaan. Dengan berfungsinya Audit Internal serta terwujudnya transparansi, akuntabilitas, efisiensi, dan efektifitas, maka terwujudlah prinsip GCG yang semakin baik dalam suatu perusahaan. Dengan demikian bahwa keberadaan Audit Internal sangat penting dalam menciptakan GCG.

\subsection{Perumusan Masalah}

1. Seberapa besar pengaruh Audit Internal terhadap penerapan Good Corporate Governance di PT. Bank XYZ?

\section{TINJAUAN PUSTAKA \\ 2.1 Definisi Audit Internal}

Berbagai definisi dari para ahli menyatakan definisi dari audit internal. The Institute of Internal Audit, yang dikutip Boynton (2001) menyatakan bahwa "Intern Auditing is an independent, objective assurance, and consulting activity designed to add value and improve organizations operations. It help an organization accomplish its objective by bringing a systematic, disciplined appoach to evaluate and improve effectiveness of risk management, control, and governance process." (Intern Auditing adalah suatu aktifitas independen, yang memberikan jaminan keyakinan serta konsultasi yang dirancang untuk memberikan suatu nilai tambah, serta meningkatkan kegiatan operasi organisasi. Intern Auditing membantu organisasi dalam usaha mencapai tujuannya dengan cara memberikan suatu pendekatan disiplin yang sistematis untuk mengevaluasi dan meningkatkan efektifitas manajemen risiko, pengendalian, proses pengaturan, dan pengelolaan organisasi).

Definisi lain mengenai audit internal juga dikemukakan oleh Mulyadi (2002:29) menyatakan bahwa audit intern adalah auditor yang bekerja dalam perusahaan (BUMN maupun swasta) yang tugas pokoknya adalah menentukan apakah kebijakan dan prosedur yang ditetapkan oleh manajemen puncak telah dipatuhi, menentukan baik tidaknya penjagaan terhadap kekayaan organisasi, menentukan efisiensi dan efektifitas prosedur kegiatan oerganisasi, serta menentukan keandalan informasi yang dihasilkan oleh berbagai bagian organisasi.

Dari beberapa definisi yang diungkapkan oleh para ahli diatas, dapat disimpulkan bahwa audit internal adalah proses pemeriksaan internal atas pengendalian yang dilakukan manajemen, untuk mengetahui efektifitas dan efisiensinya, serta untuk mengetahui penerapan setiap kegiatan usaha telah sesuai dengan kebijakan dan prosedur yang telah ditetapkan.

Pengertian audit internal diatas tidak hanya mencakup peranan dan tujuan auditor internal, tetapi juga mengakomodasi kesempatan dan tanggung jawab. Dalam perkembangan terakhir seseorang yang melakukan peran sebagaimana seorang auditor internal, tidak selalu menggunakan istilah auditor internal, namun telah meluas menjadi control maupun system analysis.

\subsection{Audit Internal Perbankan}

Dalam dunia perbankan, audit internal dibentuk dalam satuan kerja yang memiliki definisi yang sama dengan audit internal secara umumnya. Fungsi audit internal bank sangat penting karena peranan yang diharapkan dari fungsi tersebut untuk membantu senua tingkatan manajemen dalam mengamankan kegiatan operasional bank, yang melibatkan dana dari masyarakat luas. Di samping itu, menyadari kedudukan yang strategis dari perbankan dalam perekonomian, audit intern bank diharapkan juga mampu menjaga perkembangan bank ke arah yang dapat menunjang program pembangunan dari pemerintah.

Guna untuk mencapai itu semua, maka perlu diciptakan adanya kesamaan pemahaman mengenai misi, kewenangan, independency, dan ruang lingkup pekerjaan audit internal bank, Sehingga peranan tersebut dapat terwujud. Standar yang mengatur perihal pelaksanaan audit internal dalam dunia perbankan secara umum dijelaskan pada Standar Pelaksanaan Fungsi Audit Internal Bank (SPFAIB) tanggal 23 Mei 2011 yang dipakai sebagai ukuran 
minimal yang harus dipatuhi oleh semua auditor internal dalam pelaksanaan fungsi dan tugasnya yang meliputi independensi, kompetensi, program audit, pelaksanaan audit internal, pelaporan hasil audit, dan tindak lanjut atas laporan hasil pemeriksaan.

\subsection{Misi Audit Internal Bank}

Misi audit internal yang dijelaskan pada penelitian ini bersumber dari Standar Pelaksanaan Fungsi Audit Internal Bank (SPFAIB) tanggal 23 Mei 2011. Dari sumber tersebut sehingga dapat memberikan gambaran nyata mengenai standar yang dijalankan pada bank tempat penelitian ini berlangsung.

Dalam hal ini peranan audit internal sangat dibutuhkan untuk dapat menempatkan fungsinya diatas berbagai kepentingan dan untuk mengamankan harta kekayaan perusahaan, mengoptimalisasi pemanfaatan sumber daya secara ekonomis dan efisien, serta mendorong ditaatinya kebijakan manajemen yang telah digariskan.

\subsection{Fungsi Audit Internal Bank}

Tugas dari satuan kerja audit internal bank adalah membantu Direktur Utama dan Dewan Komisaris dengan menjabarkan seccara operasional perencanaan, pelaksanaan, dan pemantauan atas hasil audit. Dalam melaksanakan hal ini, auditor internal mewakili pandangan dan kepentingan profesinya dengan membuat analisis dan penelitian di bidang keuangan, akuntansi, operasional, dan kegiatan lainnya melalui mekanisme pemeriksaan. Serta memberikan saran perbaikan dan informasi yang obyektif tentang kegiatan yang direview kepada semua tingkatan manajemen (Standar Fungsi Pelaksanaan Audit Internal Bank, 2011).

\subsection{Kecukupan Aufit Internal}

Dalam rangka mencapai kecukupan fungsi audit internal, maka audit internal harus melakukan identifikasi atas segala risiko yang mungkin timbul sebagai penerapan dari audit yang berbasis risiko (Risk Based Audit), termasuk melakukan penilaian kecukupan pelaksanaan manajemen risiko bank. Termasuk dalam fungsi audit internal adalah kemungkinan untuk melakukan perbaikan dan meningkatkan efisiensi penggunaan sumber daya dan dana (Standar Pelaksanaan Fungsi Audit Internal Bank, 2011).

Oleh sebab itu dalam menjalankan fungsinya sebagai audit internal bank yang memadai, maka diperlukan tahapan seperti yang dijelaskan pada Standar Pelaksanaan Fungsi Audit Internal Bank (2011):

1. Independensi

Setiap audit internal masing-masing harus memiliki independensi dalam melakukan audit dan pengungkapan pandangan serta pemikiran sesuai dengan profesi dan standar audit yang berlaku umum. Independensi sangat penting agar hasil audit memiliki manfaat yang optimal bagi perusahaan. Dalam hubungan ini audit internal harus independen dari kegiatan yang diperiksa. Oleh karena itu audit internal dapat bekerja dengan bebas dan obyektif untuk memperoleh independensi tersebut.

2. Kompetensi

Auditor internal diharapkan memiliki kompetensi dan kemahiran profesi yang diperoleh baik melalui pendidikan maupun pengalaman kerja yang memadai dalam bidang audit internal. Audit internal tidak dituntut untuk dapat memahami seluruh bidang. Namun dalam sebuah satuan kerja setidaknya memiliki pemahaman mengenai disiplin ilmu yang diawasi.

Setiap audit internal harus memiliki sikap mental, etika, serta tanggung jawab profesi yang tinggi, sehingga kualitas hasil kerja dapat dipertanggungjawabkan dan dapat digunakan untuk membantu terwujudnya perkembangan bank yang wajar dan sehat. Sikap dan etika tersebut meliputi:

a. Kejujuran

b. Audit internal harus mampu mengemukakan pendapat secara jujur dan bijaksana, sesuai dengan hasil temuan.

c. Obyektivitas

d. Auditor internal harus selalu mempertahankan sikap obyektif, sehingga dapat mengemukakan temuan berdasarkan bukti atau fakta yang dapat dipertanggungjawabkan. Dengan demiian laporan atas hasil temuan harus lengkap dan didasarkan pada analisis yang obyektif.

e. Ketekunan

f. Auditor internal harus memiliki keetekunan dan keuletan dalam menelusuri masalah atau indikasi yang dihadapi guna memperoleh bukti yang mendukung temuannya.

g. Loyalitas

h. Auditor internal harus menunjukkan loyalitas kepada tanggung jawab profesinya. 
3. Program Audit

Pendekatan pelaksanaan audit dipengaruhi oleh besar organisasi, karakteristik, volume, dan kompleksitas operasi bagian yang diperiksa (Standar Fungsi Audit Internal Bank). Oleh karena itu, setiap pelaksanaan kegiatan audit perlu memperhatikan kondisi dari masing-masing bagian yang diperiksa.

\section{Pelaksanaan Audit Internal}

Dalam melaksanakan pemeriksaan pada unit/bagian yang diperiksa, maka auditor perlu memastikan 4 (empat) aspek yang harus diperhatikan:

a. Pelaksanaan pemeriksaan berdasarkan program audit yang telah disusun sebelum dilaksanakannnya pemeriksaan, dan apabila terdapat penambahan pengurangan wajib terdapat bukti tertulis.

b. Tahap-tahap dalam melaksanakan audit mendapatkan pengawasan dari supervisi langsung dari auditor internal.

c. Dalam pelaksanaan pemeriksaan, auditor melakukan evaluasi terhadap risiko yang timbul dari setiap aktivitas operasional, efektifitas dan efisiensi, serta kepatuhan terhadap peraturan dan hukum yang berlaku.

d. Pelaksanaan audit terhadap bagian yang diperiksa mencakup periode pemeriksaan rutin.

5. Laporan yang dihasilkan

Setelah selesai melakukan kegiatan audit, auditor intern berkewajiban untuk menuangkan hasil audit tersebut dalam bentuk laporan tertulis. Laporan tersebut harus memenuhi standar pelaporan, memuat kelengkapan materi melalui proses penyusunan yang baik. Materi yang terdapat dalam laporan harus lengkap dan jelas, laporan tersebut harus meliputi tujuan, temuan audit, kesimpulan atas hasil audit, rekomendasi, dan tanggapan. Setelah laporan selesai, maka audit internal berkewajiban untuk melaporkan kepada Direktur Utama, Dewan Komisaris, Direktur Kepatuhan, dan bagian yang di audit. Untuk selanjutnya Direktur Utama dan Dewan Komisaris menyampaikan laporan pelaksanaan dan hasil audit internal setiap semester kepada Bank Indonesia.

6. Tindak lanjut atas laporan

Sebagai tindak lanjut hasil audit, maka audit internal akan melakukan pemantauan dan analisa, serta melaporkan perkembangan pelaksanaan tindak lanjut perbaikaan yang telah dilakukan oleg bagian yang di audit. Tindak lanjut tersebut meliputi:

1) Pemantauan atas pelaksanaan tindak lanjut

Pemantauan atas pelaksanaan tindak lanjut dilakukan agar dapat diketahui perkembangan dan dapat diingatkan kepada bagian yang di audit, apabila tindak lanjut tersebut belum terselesaikan.

2) Analisis kecukupan tindak lanjut

Dari hasil pemantauan pelaksanaan tindak lanjut, dilakukan analisa kecukupan atas perbaikan yang telah dilakukan.

3) Pelaporan tindak lanjut

Apabila dalam pelaksanaan tindak lanjut tidak dilaksanakan, maka audit internal akan membuat laporan tertulis pada Direktur Utama dan Dewan Komisaris untuk tindakan lebih lanjut.

\subsection{Definisi Good Corporate Governance}

Good Corporate Governance adalah prinsip yang mengarahkan dan mengendalikan perusahaan agar mencapai keseimbangan antara kekuatan serta kewenangan perusahaan dalam memberikan pertanggungjawabannya kepada para shareholder khususnya, dan stakeholders pada umumnya (Komite Nasional Kebijakan Governance, 2006).

Selanjutnya OECD (Organization for Economic Cooperation and Development) dalam Komite Nasional Kebijakan Governance (2006) mendefinisikan GCG sebagai sekumpulan hubungan antara pihak manajemen perusahaan, pemegang saham, dan pihak lain yang mempunyai kepentingan dengan perusahaan. Corporate governance juga menyaratkan adanya struktur perangkat untuk mencapai tujuan dan pengawasan atas kinerja. Corporate governance yang baik dapat memberikan rangsangan bagi board dan manajemn untuk mencapai tujuan, yang merupakan kepentingan perusahaan dan pemegang saham harus memfasilitasi pengawasan yang efektif, sehingga mendorong perusahaan menggunakan sumber daya dengan lebih efisien (Komite Nasional Kebijakan Governance, 2006).

\subsection{Prinsip Good Corporate Governance}

Sebagai lembaga intermediasi dan lembaga kepercayaan dalam melaksanakan kegiatan usahanya, bank harus menganut prinsip keterbukaan (transparency), memiliki ukuran kinerja dari semua jajaran bank berdasarkan ukuran- 
ukuran yang konsisten dengan corporate values, sasaran usaha dan strategi bank sebagai pencerminan akuntabilitas bank (accountability), berpegang pada prudential banking practice dan menjamin dilaksakannya ketentuan yang berlaku sebagai wujud tanggung jawab bank (responsibility), objektif dan bebas dan bebas dari tekanan pihak manapun dalam pengambilan keputusan (independency), serta senantiasa memperhatikan kepentingan seluruh stakeholders berdasarkan azas kewajaran (fairness).

Oleh karena itu, bank wajib menjalankan prinsip-prinsip penerapan Good Corporate Governance sebagai berikut (SEBI No. 15/15/DPNP tanggal 29 April 2013):

1. Keterbukaan (transparency) yaitu keterbukaan dalam mengemukakan informasi yang material dan relevan, serta keterbukaan dalam pelaksanaan proses pengambilan keputusan.

2. Akuntabilitas (accountability) yaitu kejelasan fungsi dan pelaksanaan pertanggungjawaban organ bank. Sehingga pengelolaannya berjalan efektif.

3. Pertanggungjawaban (responsibility) yaitu kesesuaian pengelolaan bank dengan peraturan perundang-undangan yang berlaku, dan prinsip pengelolaan bank yang sehat.

4. Kebebasan (independency) yaitu pengelolaan bank secara profesional tanpa pengaruh/tekanan dari pihak manapun.

5. Kewajaran (fairness) yaitu keadilan dan kesetaraan dalam memenuhi hak-hak stakeholders yang timbul berdasarkan perjanjian dan peraturan perundang-undangan yang berlaku.

\subsection{Tujuan Penerapan Good Corporate Governance}

Dalam rangka meningkatkan kinerja bank, melindungi kepentingan stakeholders, dan meningkatkan kepatuhan terhadap perundang-undangan yang berlaku, serta nilai etika yang berlaku umum pada industri perbankan, bank wajib melaksanakan kegiatan usahanya yang berpedoman pada GCG, yang antara lain bertujuan untuk (Komite Nasional Kebijakan Governance, 2006):

1. Mendukung pencapaian visi dan misi;

2. Mendukung pencapaian tujuan bank melalui peningkatan kinerja yang signifikan;

3. Memaksimalkan nilai perusahaan;

4. Memberikan keyakinan pada pemegang saham dan stakeholders lainnya, bahwa pengurusan dan pengawasan bank dijalankan secara profesional;

5. Menjamin kesehatan dan kemajuan bank secara berkesinambungan;

6. Memberikan pedoman bagi Komisaris, Direksi, dan pekerja bank dalam melaksanakan tugasnya;

7. Mendukung pengelolaan sumber daya bank secara lebih efektif dan efisien;

8. Mendukung terciptanya pengambilan keputusan oleh seluruh insan bank yang didasari prinsip GCG;

9. Mendukung penetapan kebijakan bank yang didasari prinsip GCG;

10. Mendukung terwujudnya Good Corporate Citizen.

\section{Metodologi}

Kerangka berpikir yang baik akan menjelaskan secara teoritis pertautan antar variabel yang akan diteliti. Pertautan antar variabel tersebut selanjutnya dirumuskan ke dalam bentuk paradigma pennelitian yang didasarkan pada kerangka berpikir. Model penelitian yang diajukan oleh penulis adalah sebagai berikut:

\begin{tabular}{|l|l|}
\hline Audit Internal (X) & \multicolumn{1}{|c|}{$\begin{array}{c}\text { Penerapan Good Corporate } \\
\text { Governance (Y) }\end{array}$} \\
\cline { 2 - 3 } $\begin{array}{l}\text { - Independensi } \\
\text { - Kompetensi } \\
\text { - Program } \\
\text { - Audit }\end{array}$ \\
$\begin{array}{l}\text { - Pelaksanaan } \\
\text { - Hasil laporan } \\
\text { - Tindak lanjut }\end{array}$
\end{tabular}

Gambar 1. Kerangka Penelitian 


\subsection{Hipotesis}

Uji yang digunakan dalam hipotesis ini adalah uji dua pihak (two tail test), dimana uji dua pihak digunakan apabila hipotesis nol (Ho) berbunyi "sama dengan" nol yang berarti tidak ada hubungan, sedangkan hipotesis alternatifnya (Ha) berbunyi "tidak sama dengan" nol, yang berarti ada hubungan (Sugiyono 2014:216).

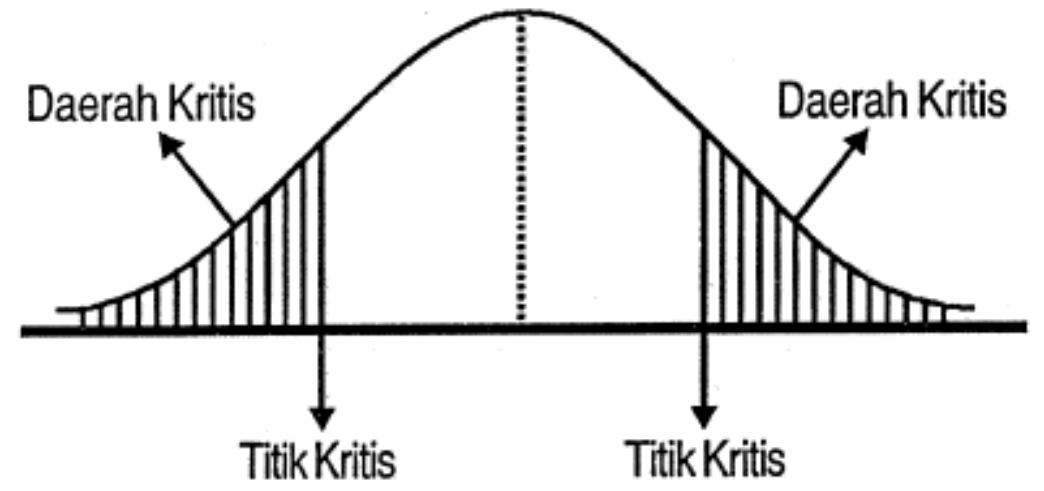

Sumber : Sugiyono (2014:217)

Gambar 2. Uji Dua Pihak

Ho $: \rho=0$ (berarti tidak ada hubungan)

Ha $: \rho \neq 0$ (berarti ada hubungan)

Jurnal Pratolo (2007) menunjukkan Audit Manajemen berpengaruh secara langsung terhadap penerapan Good Corporate Governance.

Jurnal Dzaky (2009) menunjukkan Audit internal berpengaruh secara signifikan terhadap Good Corporate Governance".

Dari dua penelitian diatas dalam maka penelitian ini dirumuskan hipotesis sebagai berikut:

Ho:Audit Internal tidak berpengaruh secara signifikan terhadap penerapan Good Corporate Governance pada PT. Bank XYZ.

Ha:Audit Internal berpengaruh secara signifikan terhadap penerapan Good Corporate Governance pada PT. Bank XYZ.

\subsection{Operasional Variabel}

Operasional varibel penelitian adalah sebuah konsep yang mempunyai penjabaran dari variabel yang ditetapkan dalam suatu penelitian dan dimaksudkan untuk memastikan agar variabel yang diteliti secara jelas dapat ditetapkan indikatornya (Sugiyono, 2014:68).

1. Variabel Independen

Pada penelitian ini yang menjadi variabel independen adalah Audit Internal. Sedangkan untuk sub variabel dan indikator dari audit internal yang menggunakan sumber dari Standar Pelaksanaan Fungsi Audit Internal Bank (SPFAIB) tanggal 23 Mei 2011 adalah sebagai berikut:

a. Independensi

1) Pemisahan fungsi audit internal dengan bagian yang diperiksa.

2) Tanggung jawab audit internal kepada Direktur Utama.

3) Kemudahan untuk memperoleh data yang dibutuhkan terhadap bagian yang diperiksa.

4) Tanggung jawab auditro kepada satuan kerja audit internal.

5) Kebebasan kepentingan auditor dengan bagian yang diperiksa.

6) Kebebasan auditor internal dalam pengungkapan temuan kepada bagian yang diperiksa.

7) Akses audit internal kepada Komite Audit.

b. Kompetensi

1) Keikutsertaan auditor dalam rangka mengembangkan kommpetensi yang diadakan oleh institusi terkait.

2) Program pengembangan kompetensi yang dilakukan secara kontinyu.

3) Latar belakang pendidikan auditor internal.

4) Latar belakang pengalaman kerja auditor internal yang terkait dengan tugas dan tanggung jawabnya. 
5) Kecakapan komunikasi auditor internal.

6) Ketelitian auditor internal dalam menjalankan tugas.

c. Program Audit

1) Kecukupan program audit atas evaluasi kegiatan operasional bagian yang diperiksa.

2) Kejelasan program audit mengenai ruang lingkup audit.

3) Review secara berkala terhadap program audit.

4) Alur penyusunan program audit.

5) Kelengkapan isi program audit terhadap bagian yang akan diperiksa.

d. Pelaksanaan Audit Internal

1) Program audit yang dijadikan acuan dalam menjalankan pemeriksaan.

2) Pengawasan terhadap tahap-tahap pemeriksaan.

3) Jangka waktu pelaksanaan pemeriksaan.

4) Evaluasi berdasarkan risiko terhadap bagian yang diperksa.

e. Laporan yang dihasikan

1) Laporan hasil pemeriksaan diterbitkan setelah pelaksanaan pemeriksaan.

2) Kejelasan isi laporan hasil pemeriksaan.

3) Ketepatan waktu dalam menerbitkan laporan hasil pemeriksaan.

4) Laporan hasil pemeriksaan mencakup rekomendasi terhadap bagian yang diperiksa.

5) Laporan hasil pemeriksaan digunakan sebagai acuan jajaran manajemen dalam mengambil keputusan.

6) Distribusi atas laporan hasil pemeriksaan.

7) Pengungkapan hasil-hasil temuan di dalam laporan hasil pemeriksaan.

f. Tindak lanjut atas laporan hasil pemeriksaan

1) Tindak lanjut manajemen atas rekomendasi auditor pada laporan hasil pemeriksaan.

2) Peran auditor dalam melakukan monitoring dan hasil dari monitoring.

2. Variabel Dependen

Pada penelitian ini yang menjadi variabel dependen adalah Penerapan GCG. Untuk sub variabel dan indikator dari GCG (SEBI No. 15/15/DPNP tanggal 29 April 2013) adalah sebagai berikut:

a. Transparansi

1) Keterbukaan manajemen dalam mengambil keputusan.

2) Kejelasan tujuan perusahaan.

3) Tindak lanjut atas penyempurnaan ketatalaksanaan.

4) Distribusi informasi yang tepat waktu.

b. Akuntabilitas

1) Tindakan Dewan Komisaris dan Direksi berdasarkan informasi yang lengkap.

2) Pengaruh keputusan dewan terhadap pemegang saham.

3) Perlakuan dewan terhadap pemegang saham.

4) Ketaatan dewan terhadap hukum perundang-undangan dan stakeholders.

c. Pertanggung jawaban

1) Penghargaan atas hak stakeholders.

2) Pembayaran pajak tepat waktu.

3) Tanggung jawab perusahaan terhadap lingkungan sekitar.

d. Kemadirian

1) Bebas intervensi dalam pengelolaan perusahaan.

2) Kepatuhan terhadap perundang-undangan dalam melaksanakan kegiatan perusahaan.

e. Kewajaran

1) Pemenuhan hak pemegang saham.

2) Kesempatan pemegang saham memberikan suara pada RUPS.

3) Pembagian dividen yang adil kepada pemegang saham.

4) Informasi yang akurat bagi stakeholders.

\subsection{Populasi dan Sampel}

Dalam penelitian ini keseluruhan populasi dari satuan kerja audit internal menjadi sampel.

Teknik sampling yang digunakan dalam penelitian ini adalah Nonprobability Sampling dengan cara sampling jenuh yaitu teknik penentuan sampel bila semua anggota populasi digunakan sebagai sampel (Sugiyono, 2014:126). 
Dalam hal ini keseluruhan populasi dari satuan kerja audit Internal Bank XYZ menjadi sampel. Jumlah responden sebanyak 25 orang yang merupakan auditor internal dari PT. Bank XYZ.

\subsection{Metode Pengujian Data}

Uji validitas dilakukan untuk mengetahui sejauh mana data dalam kuesioner dapat diukur validitasnya. Untuk uji validitas ini digunakan teknik Pearson Correlation yaitu mengkorelasikan skor setiap item dengan skor total. Uji reliabilitas menunjukkan konsistensi dari data yang dikumpulkan. Teknik yang digunakan dalam menguji reliabilitas adalah Cronbach's Alpha. Uji normalitas ditujukan untuk mengetahui distribusi penyampelan data yang digunakan apakah telah terdistribusi secara normal yang merupakan distribusi teoritis dari variabel acak yang continue. Untuk menguji, maka digunakan pengujian Kolmogorov Smirnov (k-s) satu sampel. Sebelum dilakukan pengujian hipotesis, dilakukan pengujian Uji multikolinearitas, bertujuan untuk menguji apakah model regresi ditemukan adanya korelasi antar variabel bebas (independen). Kemudian Uji heterokedastisitas bertujuan untuk melihat apakah terdapat ketidaksamaan varians dari residual satu pengamatan ke pengamatan yang lain. Kemudian Uji autokorelasi bertujuan menguji apakah model regresi linier ada korelasi antara kesalahan pengganggu pada periode $t$ dengan kesalahan pengganggu pada periode sebelumnya.

\subsection{Uji Hipotesis}

Untuk menguji hipotesis pada penelitian ini, maka digunakan uji signifikansi, uji determinasi, dan uji regresi. Secara rinci dijabarkan sebagai berikut:

1. Uji Regresi

Model yang digunakan untuk menganalisis pengaruh dari berbagai variabel independen terhadap satu variabel dependen.

$$
\mathrm{Y}=\alpha+\mathrm{bX}
$$

Y : Penerapan Good Corporate Governance

$\alpha \quad$ : Konstanta

b : Koefisien Regresi

X : Audit Internal

2. Uji signifikansi

Setelah memperoleh nilai "r" kemudian untuk mengetahui signifikansi regresi, maka dilakukan pengujian signifikansi dengan menggunakan rumus " $\mathrm{t}$ "

$$
\text { t hitung }=\frac{r \sqrt{(n-2)}}{\sqrt{1-r^{2}}}
$$

r $\quad$ : Koefisien Korelasi

n : Jumlah responden

3. Uji Determinasi

Rsquare digunakan untuk melihat besarnya pengaruh audit internal terhadap penerapan Good Corporate Governance (GCG) dengan cara menghitung Koefisien Determinasi (KD) dengan menggunakan rumus sebagai berikut:

$\begin{array}{ll}\mathrm{KD} & : \text { Koefisien Determinasi } \\ \mathrm{r}^{2} & : \text { Rsquare }\end{array}$

\section{Hasil dan Pembahasan}

Data primer berupa Kuesioner sebanyak 25 buah disebarkan kepada Auditor Internal Bank XYZ, dan kuesioner yang kembali sebanyak 25 buah. Instrumen pertanyaan pada kuesioner mencakup pengaruh audit internal dan penerapan Good Corporate Governance (GCG). Sebanyak 31 pertanyaan untuk instrumen audit internal, dan 22 pertanyaan untuk instrumen Good Corporate Governance (GCG). Untuk mendapatkan data sekunder, penulis melakukan riset langsung di Bank XYZ. 


\subsection{Uji Validitas}

Pengujian validitas dari instrumen penelitian dilakukan dengan menghitung angka korelasi atau $r$ hitung dari nilai jawaban tiap responden tiap butir pertanyaan. Kemudian dibandingkan dengan $\mathrm{r}$ tabel. Nilai $\mathrm{r}$ tabel didapat dari $\mathrm{n}-2, \mathrm{n}$ adalah jumlah responden. Maka 25-2=23 dengan tingkat signifikansi 5\%. Maka didapat $\mathrm{r}$ tabel 0,3961.

Tabel 1.Uji Validitas Audit Internal

\begin{tabular}{|c|c|c|c|}
\hline Pertanyaan & Nilai r hitung & Nilai $r$ tabel & Kriteria \\
\hline 1 & 0.680 & 0.396 & Valid \\
\hline 2 & 0.493 & 0.396 & Valid \\
\hline 3 & 0.516 & 0.396 & Valid \\
\hline 4 & 0.649 & 0.396 & Valid \\
\hline 5 & 0.680 & 0.396 & Valid \\
\hline 6 & 0.745 & 0.396 & Valid \\
\hline 7 & 0.649 & 0.396 & Valid \\
\hline 8 & 0.529 & 0.396 & Valid \\
\hline 9 & 0.480 & 0.396 & Valid \\
\hline 10 & 0.508 & 0.396 & Valid \\
\hline 11 & 0.745 & 0.396 & Valid \\
\hline 12 & 0.624 & 0.396 & Valid \\
\hline 13 & 0.716 & 0.396 & Valid \\
\hline 14 & 0.621 & 0.396 & Valid \\
\hline 15 & 0.694 & 0.396 & Valid \\
\hline 16 & 0.616 & 0.396 & Valid \\
\hline 17 & 0.727 & 0.396 & Valid \\
\hline 18 & 0.641 & 0.396 & Valid \\
\hline 19 & 0.708 & 0.396 & Valid \\
\hline 20 & 0.686 & 0.396 & Valid \\
\hline 21 & 0.624 & 0.396 & Valid \\
\hline 22 & 0.672 & 0.396 & Valid \\
\hline 23 & 0.643 & 0.396 & Valid \\
\hline 24 & 0.602 & 0.396 & Valid \\
\hline 25 & 0.716 & 0.396 & Valid \\
\hline 26 & 0.636 & 0.396 & Valid \\
\hline 27 & 0.724 & 0.396 & Valid \\
\hline 28 & 0.727 & 0.396 & Valid \\
\hline 29 & 0.641 & 0.396 & Valid \\
\hline 30 & 0.708 & 0.396 & Valid \\
\hline 31 & 0.724 & 0.396 & Valid \\
\hline
\end{tabular}

Berdasarkan data diatas, hasil uji validitas audit internal menunjukkan seluruh instrumen valid. Dengan nilai $r$ hitung $>r$ tabel. 
Tabel 2. Uji Validitas GCG

\begin{tabular}{cccc}
\hline Pertanyaan & Nilai $r$ hitung & Nilai $r$ tabel & Kriteria \\
\hline 1 & 0.650 & 0.396 & Valid \\
2 & 0.701 & 0.396 & Valid \\
3 & 0.625 & 0.396 & Valid \\
4 & 0.549 & 0.396 & Valid \\
5 & 0.582 & 0.396 & Valid \\
6 & 0.460 & 0.396 & Valid \\
7 & 0.730 & 0.396 & Valid \\
8 & 0.548 & 0.396 & Valid \\
9 & 0.466 & 0.396 & Valid \\
10 & 0.635 & 0.396 & Valid \\
11 & 0.592 & 0.396 & Valid \\
12 & 0.827 & 0.396 & Valid \\
13 & 0.596 & 0.396 & Valid \\
14 & 0.689 & 0.396 & Valid \\
15 & 0.625 & 0.396 & Valid \\
16 & 0.638 & 0.396 & Valid \\
17 & 0.585 & 0.396 & Valid \\
18 & 0.803 & 0.396 & Valid \\
19 & 0.548 & 0.396 & Valid \\
20 & 0.644 & 0.396 & Valid \\
21 & 0.719 & 0.396 & Valid \\
22 & 0.460 & 0.396 & Valid \\
\hline
\end{tabular}
$>\mathrm{r}$ tabel.

Berdasarkan data diatas, hasil uji validitas GCG menunjukkan seluruh instrumen valid. Dengan nilai $r$ hitung

\subsection{Uji Reliabilitas}

Kuesioner yang telah terjawab dan dapat digunakan sebagai alat analisa, selanjutnya dilakukan pengelompokan untuk item pertanyaan, dan menentukan nilai masing-masing variabel dari jumlah pertanyaan yang digunakan untuk mengukur variabel, lalu dialkukan pengujian variabel menggunakan teknik cronbach alpha. Jika nilai korelasi sama dengan atau lebih besar dari 0,6 maka instrumen dikatakan handal (Ghozali, 2005).

Tabel 3. Uji reliabilitas instrumen audit internal

\section{Reliability Statistics}

\begin{tabular}{|r|r|}
\hline $\begin{array}{c}\text { Cronbach } \\
\text { s Alpha }\end{array}$ & N of Items \\
\hline .950 & 31 \\
\hline
\end{tabular}

Tabel 4. Uji reliabilitas instrumen GCG

Reliability Statistics

\begin{tabular}{|r|r|}
\hline $\begin{array}{c}\text { Cronbach' } \\
\text { s Alpha }\end{array}$ & N of Items \\
\hline .926 & 22 \\
\hline
\end{tabular}


Dari hasil diatas dapat diketahui setiap pertanyaan dari masing-masing instrumen menghasilkan nilai diatas 0,6 . Variabel audit internal menghasilkan nilai sebesar 0,950 , sedangkan untuk variabel GCG menghasilkan nilai sebesar 0,926 .

Berdasarkan uji reliabilitas, maka dapat diketahui masing-masing instrumen pertanyaan pada variabel audit internal dan variabel GCG dinilai handal (reliable) untuk digunakan sebagai penelitian.

\subsection{Uji Normalitas Data}

Uji normalitas data dilakukan untuk mengetahui apakah data terdistribusi dengan normal. Untuk menguji normalitas data maka digunakan teknik kolmogorov smirnov satu sampel. Langkah pertama ditentukan hipotesis pengujian, yaitu:

Hipotesis Nol (Ho) : Data terdistribusi normal

Hipotesis alternatif $(\mathrm{Ha}) \quad$ : Data tidak terdistribusi normal

Jika Asymp Sig (2 tailed) > 0,05 maka data tersebut terdistribusi secara normal, sebaliknya jika Asymp Sig ( 2 tailed) $<0,05$ maka data tidak terdistribusi secara normal.

Tabel 5. Uji Normalitas

One-Sample Kolmogorov-Smirnov Test

\begin{tabular}{|ll|r|r|}
\hline & & \multicolumn{1}{|c|}{$\begin{array}{c}\text { AUDIT } \\
\text { INTERNAL }\end{array}$} & $\begin{array}{c}\text { GOOD } \\
\text { CORPORATE } \\
\text { GOVERNANCE }\end{array}$ \\
\hline Normal Parameters ${ }^{\mathrm{a}, \mathrm{b}}$ & Mean & 25 & 25 \\
& Std. & 120.4800 & 80.0800 \\
& Deviation & 11.28096 & 8.54361 \\
Most Extreme Differences & Absolute & .107 & .118 \\
& Positive & .084 & .076 \\
& Negative & -.107 & -.118 \\
Kolmogorov-SmirnovZ & & .537 & .588 \\
Asymp. Sig. (2-tailed) & & .935 & .879 \\
\hline
\end{tabular}

Dari hasil pengujian normalitas pada tabel 4.5 tampak bahwa tingkat signifikansi variabel audit internal adalah sebesar 0,935, sedangkan tingkat signifikansi GCG sebesar 0,879. Nilai tersebut lebih besar dari 0,05. Hal ini menyatakan bahwa hipotesis nol (Ho) dapat diterima, dengan kata lain variabel audit internal dan variabel GCG terdistribusi secara normal. Begitu pula dengan nilai kolmogorov smirnov dari variabel audit internal dan variabel GCG terdistribusi secara normal.

\subsection{Uji Asumsi Multikolinearitas}

Pengambilan keputusan dalam uji asumsi multikolinearitas dari nilai toleransi dan VIF yaitu :

1. Nilai toleransi :

a. Jika nilai toleransi lebih besar dari 0,10 maka tidak terjadi multikolinearitas.

b. Jika nilai toleransi lebih kecil atau sama dengan 0,10 maka terjadi multikolinearitas.

2. Nilai VIF (Variant Inflation Factor)

a. Jika nilai VIF lebih kecil dari 10,00 maka tidak terjadi multikolinearitas.

b. Jika nilai VIF lebih besar atau sama dengan 10,00 maka terjadi multikolinearitas. 
Tabel 6. Uji Asumsi Multikolinearitas

Coefficientsa

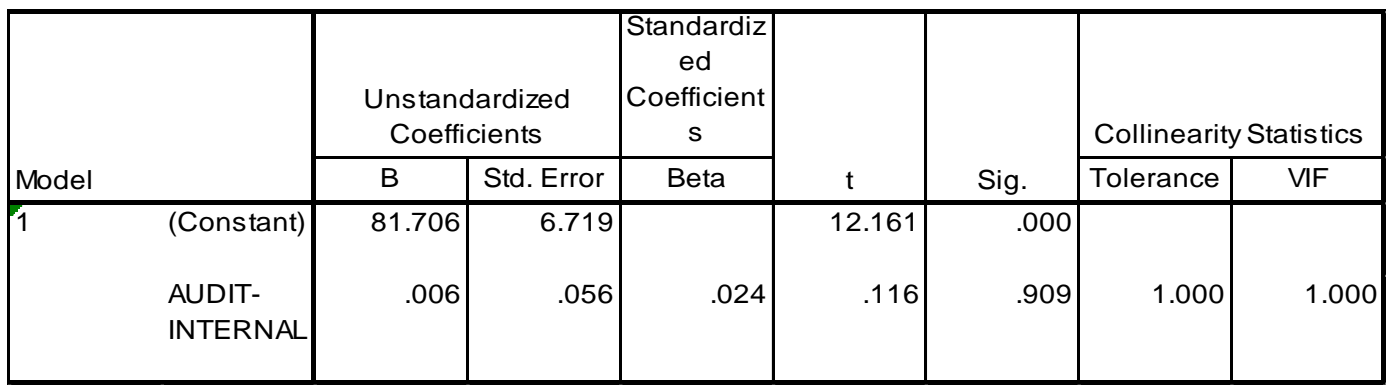

Berrdasarkan hasil uji asumsi multikolinearitas diatas, tampak nilai toleransi sebesar 1,00 >0,10. Sehingga variabel bebas dapat disimpulkan tidak terjadi multikolinearitas. Sedangkan untuk nilai VIF diperoleh hasil sebesar $1,00<10,00$. Sehingga variabel bebas disimpulkan tidak terjadi multikolinearitas.

\subsection{Uji Heterokedastisitas}

Model regresi yang baik adalah tidak terjadi heterokedastisitas. Dasar pengambilan keputusan pada uji heterokedastisitas adalah :

a. Jika nilai $\mathrm{t}$ hitung lebih kecil dari $\mathrm{t}$ tabel dan nilai signifikansi lebih besar dari 0,05 maka tidak terjadi heterokedastisitas.

b. Jika nilai $\mathrm{t}$ hitung lebih besar dari t tabel dan nilai signifikansi lebih kecil dari 0,05 maka terjadi heterokedastisitas.

Sebelum dilakukan pengujian, terlebih dahulu menetukan nilai $\mathrm{t}$ tabel. Nilai $\mathrm{t}$ tabel didapat dari $\mathrm{n}-2, \mathrm{n}$ adalah jumlah ressponden. Maka 25-2=23 dengan tingkat signifikansi 5\%. Maka didapat t tabel 2,069.

Tabel 7. Uji Heterokedastisitas

\section{Coefficientsa}

\begin{tabular}{|c|c|c|c|c|c|c|}
\hline \multirow[b]{2}{*}{ Model } & & \multicolumn{2}{|c|}{$\begin{array}{c}\text { Unstandardized } \\
\text { Coefficients }\end{array}$} & \multirow{2}{*}{$\begin{array}{c}\begin{array}{c}\text { Standardiz } \\
\text { ed } \\
\text { Coefficient } \\
\text { s }\end{array} \\
\text { Beta }\end{array}$} & \multirow[b]{2}{*}{$\mathrm{t}$} & \multirow[b]{2}{*}{ Sig. } \\
\hline & & $B$ & Std. Error & & & \\
\hline 1 & (Constant) & 16.787 & 3.896 & & 4.309 & .000 \\
\hline & $\begin{array}{l}\text { AUDIT- } \\
\text { INTERNAL }\end{array}$ & -.118 & .032 & -.608 & -3.674 & .001 \\
\hline
\end{tabular}

Dari hasil diatas, maka diketahui perbandingan nilai $t$ hitung dan $t$ tabel adalah $-3,674<2,069$. Maka disimpulkan tidak terjadi heterokedastisitas. Namun nilai signifikansi adalah $0,01<0,05$. Maka disimpulkan terjadi heterokedastisitas.

Disamping menggunakan uji glejser, dalam menguji heterokedastisitas penelitian ini, digunakan pula uji grafik scatterplot. 


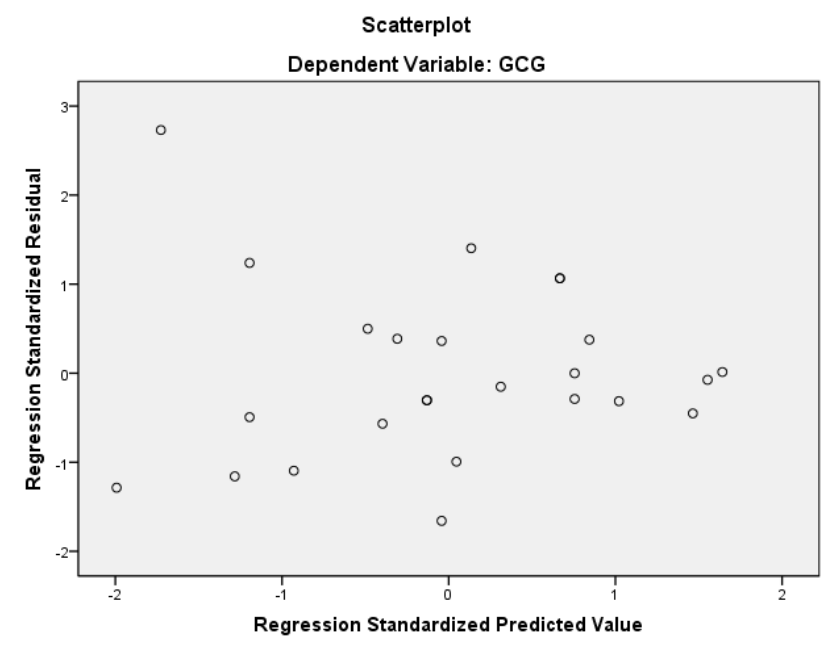

Gambar 3.Grafik Scatterplot

Dari hasil diatas dapat diketahui bahwa titik-titik tidak membentuk pola yang jelas, menyebar diatas dan dibawah angka nol sumbu Y. Sehingga dapat disimpulkan tidak terjadi heterokedastisitas pada model regresi.

\subsection{Uji Autokorelasi}

Dalam menguji autokorelasi digunakan uji Durbin-Watson. Dasar pengambilan keputusan dalam uji autokorelasi adalah:

a. Jika d lebih kecil dari dL atau lebih besar dari (4-dL) maka hipotesis nol ditolak, yang berarti terdapat autokorelasi.

b. Jika d terletak antara dU dan (4-dU) maka hipotesis nol diterima, yang berarti tidak terdapat autokorelasi.

c. Jika d terletak antara dL dan dU atau diantara (4-dU) dan (4-dL), maka tidak menghasilkan kesimpulan yang pasti.

Tabel 8. Uji Autokorelasi

Model Summaryb

\begin{tabular}{|l|r|r|r|r|r|}
\hline Model & R & R Square & $\begin{array}{c}\text { Adjusted } \\
\text { R Square }\end{array}$ & $\begin{array}{c}\text { Std. Error } \\
\text { of the } \\
\text { Estimate }\end{array}$ & $\begin{array}{c}\text { Durbin- } \\
\text { Watson }\end{array}$ \\
\hline 1 & .918 & .842 & .836 & 3.46466 & 1.482 \\
\hline
\end{tabular}

Dari hasil diatas, diketahui nilai DW 1,482. Nilai tersebut dibandingkan dengan nilai tabel signifikansi 5\%, dengan jumlah sampel 25 (n) dan jumlah variabel 2. Diperoleh nilai dU 1,549. Nilai DW 1,482 kurang dari atau diantara 1,549, dan kurang dari (4-dU) 4-1,549=2,450 dapat disimpulkan bahwa tidak terdapat autokorelasi.

\subsection{Pengujian Hipotesis secara Simultan}

Hipotesis atas pengaruh audit internal terhadap penerapan Good Corporate Governance (GCG) ditetapkan sebagai berikut:

Ho : Audit internal tidak berpengaruh secara signifikan terhadap penerapan Good Corporate Governance (GCG).

Ha : Audit internal berpengaruh secara signifikan terhadap penerapan Good Corporate Governance (GCG).

Dasar pengambilan keputusan yaitu membandingkan nilai t hitung dengan $t$ tabel. Atau membandingkan nilai signifikansi dengan nilai porbabilitas 0,05 .

1. Membandingkan nilai t hitung dan $t$ tabel :

a. Jika nilai $t$ hitung lebih besar dari nilai $t$ tabel maka variabel audit internal berpengaruh terhadap penerapan GCG. 
b. Jika nilai t hitung tidak lebih besar dari nilai t tabel maka variabel audit internal tidak berpengaruh terhadap penerapan GCG.

2. Membandingkan nilai signifikansi dengan probabilitas 0,05 :

a. Jika nilai signifikansi tidak lebih dari nilai probabilitas 0,05 maka variabel audit internal berpengaruh terhadap penerapan GCG.

b. Jika nilai signifikansi lebih dari nilai probabilitas 0,05 maka variabel audit internal tidak berpengaruh terhadap penerapan GCG.

Tabel 9. Model Summary Regresi Linier

\begin{tabular}{|l|r|r|r|r|}
\multicolumn{7}{|c}{ Model Summary } \\
\hline Model & $\mathrm{R}$ & R Square & $\begin{array}{c}\text { Adjusted } \\
\text { R Square }\end{array}$ & $\begin{array}{c}\text { Std. Error } \\
\text { of the } \\
\text { Estimate }\end{array}$ \\
\hline 1 & .918 & .842 & .836 & 3.46466 \\
\hline
\end{tabular}

Dari output diatas, diketahui nilai korelasi (r) adalah 0,918, sedangkan $\mathrm{r}^{2}$ adalah 0,842 . Hal ini berarti pengaruh variabel audit internal terhadap variabel penerapan GCG adalah sebesar 84,2\%, sedangkan sisanya dipengaruhi faktor lain.

Tabel 10. Annova Regresi Linier

ANOVAb

\begin{tabular}{|c|c|c|c|c|c|c|}
\hline Model & & $\begin{array}{c}\text { Sum of } \\
\text { Squares }\end{array}$ & df & $\begin{array}{l}\text { Mean } \\
\text { Square }\end{array}$ & $\mathrm{F}$ & Sig. \\
\hline \multirow[t]{3}{*}{1} & $\begin{array}{l}\text { Regressio } \\
\mathrm{n}\end{array}$ & 1475.751 & 1 & 1475.751 & 122.940 & .000 \\
\hline & Residual & 276.089 & 23 & 12.004 & & \\
\hline & Total & 1751.840 & 24 & & & \\
\hline
\end{tabular}

Dari hasil diatas, dapat diketahui pengaruh signifikan variabel audit internal terhadap variabel penerapan GCG. Dari output diatas menunjukkan F hitung = 122,940 dengan tingkat signifikansi $0,000<0,05$, maka model regresi dapat digunakan untuk memprediksi variabel penerapan GCG.

Tabel 11.Coefficientsa Regresi Linier

\section{Coefficientsa}

\begin{tabular}{|c|c|c|c|c|c|c|}
\hline \multirow[b]{2}{*}{ Model } & & \multicolumn{2}{|c|}{$\begin{array}{l}\text { Unstandardized } \\
\text { Coefficients }\end{array}$} & \multirow{2}{*}{\begin{tabular}{|c}
$\begin{array}{c}\text { Standardiz } \\
\text { ed } \\
\text { Coefficient } \\
\text { s }\end{array}$ \\
Beta
\end{tabular}} & \multirow[b]{2}{*}{$t$} & \multirow[b]{2}{*}{ Sig. } \\
\hline & & $B$ & Std. Error & & & \\
\hline \multirow[t]{2}{*}{1} & (Constant) & -3.667 & 7.585 & & -.483 & .633 \\
\hline & $\begin{array}{l}\text { AUDIT- } \\
\text { INTERNAL }\end{array}$ & .695 & .063 & .918 & 11.088 & .000 \\
\hline
\end{tabular}

Dari hasil diatas diketahui nilai a adalah $-3,667$ sedangkan nilai b adalah 0,695 . Sehingga persamaan regresi adalah:

$\mathrm{Y}=\mathrm{a}+\mathrm{bX}$ atau $-3,667+0,695 \mathrm{X}$

Setelah memperoleh nilai $\mathrm{r}$, kemudian untuk mengetahui signifikansi regresi, maka dilakukan pengujian signifikansi dengan menggunakan rumus $t$, dengan rumus sebagai berikut : 


$$
\frac{r \sqrt{n-2}}{\sqrt{1-r^{2}}}
$$

Kemudian dari rumus diatas, dari hasil uji regresi linear diatas didapat output sebagai berikut:

$$
\begin{gathered}
\frac{0,918 \sqrt{25-2}}{\sqrt{1-0,918^{2}}} \\
=11,088
\end{gathered}
$$

Dari output diatas dapat diketahui nilai t hitung adalah 11,088 lebih besar dari t tabel 2,069, dengan nilai signifikansi $0,000<0,05$. Maka mengacu pada hipotesis diatas, Ho ditolak, dan Ha diterima. Dapat disimpulkan terdapat pengaruh yang signifikan dari variabel audit internal terhadap variabel penerapan GCG.

Selanjutnya, untuk melihat pengaruh audit internal terhadap penerapan GCG, digunakan uji deterrminasi dengan rumus koefisien determinasi menggunakan rumus sebagai berikut:

$$
\begin{gathered}
\mathrm{KD}=\mathrm{r}^{2} \times 100 \% \\
=0,918^{2} \times 100 \% \\
=0,843=84 \%
\end{gathered}
$$

Dari hasil diatass, diketahui bahwa pengaruh audit internal sebesar $84 \%$ dari penerapan GCG, sedangkan $16 \%$ sisanya ddipengaruhi oleh variabel lain yang tidak termasuk di dalam penelitian ini.

\section{Penutup \\ 5.1 Kesimpulan}

Penelitian ini bertujuan untuk mengetahui seberapa besar pengaruh audit internal, terhadap penerapan Good Corporate Governance (GCG). Pengujian dalam penelitian ini menggunakan uji regresi linier sedarhana kepada responden auditor internal yang bekerja di Bank XYZ, hasil penelitian disimpulkan sebagai berikut :

1. Audit internal (X) berpengaruh signifikan terhadap penerapan Good Corporate Governance (GCG) sebesar $84 \%$, sedangkan sisanya sebesar $16 \%$ dipengaruhi oleh faktor lain yang tidak masuk dalam penelitian ini. Sehingga hipotesis alternatif (Ha) diterima dengan kesimpulan audit internal berpengaruh secara signifikan terhadap penerapan Good Corporate Governance (GCG) pada PT. Bank XYZ.

\subsection{Implikasi}

Regulasi Bank Indonesia yang mewajibkan bank umum yang beroperasi di Indonesia untuk menjalankan prinsip tata kelola perusahaan yang baik. Pengelolaan suatu bank bergantung pada berbagai macam faktor, termasuk budaya perusahaan, SDM, serta struktur kepemilikan bank. Struktur kepemilikan yang dimiliki oleh 1 orang/institusi, mengakibatkan timbulnya campur tangan maupun konflik kepentingan antar individu. Akibat faktor budaya yang telah mengakar dalam sebuah perusahaan, menjadikan penerpan GCG bukan perkara yang sederhana. Keberadaan auditor internal menjadi sangat penting karena perannya sebagai pihak yang independen, objektif, dan tidak bergantung pada satu pihak. Pada akhirnya dapat meningkatkan citra bank yang baik di kalangan investor, kreditur, pemerintah, dan tentunya masyarakat luas sebagai pengguna jasa perbankan.

\subsection{Saran}

Alangkah baiknya kesadaran dalam penerapan GCG bukan hanya menjadi tanggung jawab dari auditor internal, melainkan menjadi kesadaran yang dimiliki oleh setiap karyawan. Dengan begitu kualitas penerapan GCG semakin baik. Dan hasilnya dapat meningkatan citra bank yang baik bagi kalangan investor, kreditur, pemerintah, dan tentunya masyarakat luas sebagai pengguna jasa perbankan.

Diharapkan pada penelitian selanjutnya dapat meneliti faktor-faktor lain yang mempengaruhi penerapan GCG di dunia perbankan, selain peran audit internal tentunya. Selain itu diperlukan objek yang lebih beragam, terutama perbankan di Indonesia yang masih belum go public. Sehingga dapat diketahui seberapa besar kepatuhan bank dalam menerapkan GCG.

\section{Daftar Pustaka}

Akmal. (2006). Pemeriksaan Intern (Internal Audit). Jakarta: PT. Indeks Kelompok Gramedia. 
Bagus, I. (n.d.). 69,3\% Bank belum penuhi GCG. Retrieved from www.detikfinance.com diakses tanggal 26 April 2015.

Bank Indonesia. (2006). Peraturan Bank Indonesia No. 8/4/PBI/2006. Retrieved from www.bi.go.id diakses tanggal 9 April 2015.

BANK INDONESIA. (2007). Surat Edaran Bank Indonesia No. 9/12/DPNP. Retrieved from www.bi.go.id diakses tanggal 9 April 2015.

BANK INDONESIA. (2010). Peraturan Bank Indonesia No. 12/21/PBI/2010. Retrieved from www.bi.go.id diakses tanggal 9 April 2015.

BANK INDONESIA. (2013). Surat Edaran Bank Indonesia No. 15/15/DPNP. Retrieved from www.bi.go.id diakses tanggal 9 April 2015

Boynton, Johnson, \& Kell. (2006). Modern Auditing. Jakarta: Erlangga.

Dzaky, V. (2009). Peran Audit Internal Dalam Upaya Mewujudkan Good Corporate Governance. Bandung:Universitas Widyatama. Retrieved from repository.widyatama.ac.id diakses tanggal 14 Maret 2015

Ghozali, I. (2005). Aplikasi Analisis Multivariate dengan Program SPSS. Semarang: Badan Penerbit Universitas Diponegoro.

Hery. (2010). Potret Profesi Audit Internal. Bandung: Alfabeta.

Komite Nasional Kebijakan Governance. (2006). Pedoman Umum Good Corporate Governance. Retrieved from www.governance-indonesia.or.id diakses tanggal 9 April 2015.

Mulyadi. (2002). Auditing Buku 1. Jakarta: Salemba Empat.

PT. Bank XYZ. (2011). Standar Pelaksanaan Fungsi Audit Internal Bank. Surabaya.

Pratolo, S. (2007). Good Corporate Governance dan Kinerja BUMN di Indonesia. Makassar: Simposium Nasional Akuntansi X.

Santoso, S. (2002). Mengolah Data Statistik Secara Profesional. Jakarta: Elex Media Komputindo. 